\title{
RENCANA BISNIS PETERNAKAN AYAM RAS PETELUR PT. SINAR FARM DI PROVINSI MALUKU
}

\author{
Prasetyo \\ Program Studi Magister Manajemen Universitas Tarumanagara \\ danielprasetyo5@gmail.com
}

\begin{abstract}
The level of consumption for eggs in Maluku can not be fulfilled by local production, therefore there is a need of supply from other regions such as Makassar and Surabaya. This situation opens for dependence on the supply of eggs from other regions is very high, which indicates that there is an opportunity for business and large market share for this business in Maluku. Seeing the opportunities that exist, the idea to open a layer farming in Maluku is feasible to be implemented. The marketing targets of the products are retail merchants in the market, grocery stores and collective merchant between regions. In this business plan, there are income statement and cash flow statement of the company for the next 5 years. Based on calculations that have been done, the results of the Net Present Value (NPV) is positive, and payback period is faster than the time specified. Thus, it can be concluded that investment in layer farming is feasible and profitable.
\end{abstract}

Keywords : Layer Farming, Net Present Value, Payback Period, Maluku, Business Plan.

\section{PENDAHULUAN}

Tidak dapat dipungkiri bahwa saat ini, telur ayam menjadi salah satu kebutuhan pokok masyarakat Indonesia. Harga yang terjangkau disertai kandungan protein yang tinggi dan rasa yang enak, membuat telur ayam populer di berbagai lapisan masyarakat. Selain dapat diolah menjadi berbagai macam masakan, telur ayam juga dapat digunakan dalam produk olahan kue dan roti. Dengan beragamnya produk olahan ini membuat tingkat konsumsi telur ayam tinggi. Telur ayam yang banyak beredar di masyarakat sebagian besar berasal dari peternakan ayam ras petelur. Peternakan ayam ras petelur mulai berkembang di Indonesia sejak tahun 1990-an hingga saat ini. Seiring dengan bertambahnya jumlah penduduk dan meningkatnya tingkat perekonomian masyarakat, menjadikan kebutuhan akan telur ayam terus meningkat.

Berdasarkan sensus pertanian yang dilakukan oleh Badan Pusat Statistik (BPS) pada tahun 2013, terdapat 29.939 peternakan ayam ras petelur di seluruh wilayah Indonesia dengan jumlah populasi sebesar 146.621.514 ekor ayam dengan total produksi 1.224.400 ton telur. Pada tahun 2014, populasi ayam ras petelur naik menjadi 146.660 .415 ekor ayam dengan total produksi 1.244.312 ton telur. Pada tahun 2015 dan 2015 terjadi kenaikan populasi yang signifikan yaitu 155.007.388 ekor pada tahun 2015 dan 161.349.806 ekor pada tahun 2016 . Jumlah produksi telur juga mengalami peningkatan seiring dengan bertambahnya populasi ayam yaitu 1.372 .829 ton telur pada 2015 dan pada tahun 2016 sebanyak 1.485 .688 ton telur.

Untuk provinsi Maluku menurut data sensus pertanian tahun 2013, hanya terdapat 4 peternakan ayam ras petelur dengan populasi ayam 10.595 ekor dan jumlah produksi telur sebesar 83 ton telur. Populasi ini sendiri mengalami peningkatan yang sangat signifikan pada tahun 2014 yaitu 20.539 ekor ayam dengan jumlah produksi telur ayam sebesar 155 ton. Namun pada tahun 2015, populasi ayam ras petelur di Maluku mengalami penurunan populasi lebih dari 50\% dari tahun sebelumnya menjadi 9.567 ekor ayam dengan jumlah produksi sebesar 72 ton. Populasi ayam naik kembali pada tahun 2016 menjadi 19.270 ekor ayam dengan jumlah produksi telur sebesar 145 ton. Menurut data dari Dinas Pertanian Provinsi Maluku, pada tahun 2016 kebutuhan akan telur ayam ras di Maluku mencapai 9.509 ton. Melihat kondisi dimana kebutuhan akan telur ayam ras di Maluku bergantung pada pasokan dari daerah lain, Kepala Dinas Pertanian Maluku, Diana Padang, terus mendorong 
masyarakat untuk mengembangkan usaha ayam ras petelur. Pihaknya juga, kata Diana, akan memberikan fasilitas bantuan bagi usaha peternakan ayam ras petelur. Berdasarkan data diatas, dapat diambil kesimpulan bahwa berbisnis ayam ras petelur di provinsi Maluku memiliki peluang bisnis yang menjanjikan.

Dalam studi ini, akan dijelaskan mengenai proses manajemen dari bisnis ini dan bagaimana kelayakan investasi dari bisnis peternakan ayam ras petelur yang dilakukan PT. Sinar Farm. Dengan adanya penjelasan mengenai proses manajemen yang akan dilakukan oleh PT. Sinar Farm, diharapkan dapat menjadi pedoman bagi pihak-pihak yang ingin memulai bisnis peternakan ayam ras petelur. Sedangkan, kelayakan investasi yang ada diharapkan dapat menjadi pedoman bagi investor dalam pengambilan keputusan guna berinvestasi pada bisnis ini.

\section{METODE PENELITIAN}

Penelitian terhadap rencana bisnis peternakan ayam ras petelur oleh PT. Sinar Farm di Provinsi Maluku merupakan penelitian kepustakaan dan menggunakan metode analisis kuantitatif. Dimana dalam penelitian ini, data-data sekunder yang didapat baik melalui buku, internet, dan literatur lainnya dijadikan sebagai referensi dalam menyusun rencana bisnis ini. Data-data pendukung berupa angka-angka yang digunakan dalam menghitung kelayakan investasi didapat dari Badan Pusat Statistik (BPS) dan Dinas Pertanian Maluku, dimana merupakan data yang berasal dari tahun 2015 hingga tahun 2017. Pada penelitian ini, nilai waktu terhadap uang tidak dihitung. Asumsi yang dipakai dalam perhitungan ini adalah harga telur Rp 1.500,- per butir, harga kotoran ayam Rp 5.000,- per karung, harga ayam afkir Rp 35.000 ,- per ekor, suku bunga yang digunakan adalah suku bunga kredit retail dari bank BRI pada Mei 2018 yaitu sebesar 9.75\%, tingkat mortalitas 6\%, dan penjualan berjalan sesuai perkiraan. Pada penelitian ini, akan dilakukan analisis terhadap NPV dan Payback Period yang didapat dari perhitungan laporan laba rugi dan laporan arus kas, untuk menentukan kelayakan investasi pada usaha ini.

\section{HASIL DAN PEMBAHASAN}

\section{Analisis Pasar}

Pada tahun 2015, kebutuhan telur ayam ras di Maluku dalam setahun mencapai 9.341 ton, sedangkan kemampuan produksi peternak lokal hanya 72,04 ton per tahun. Pada tahun 2016, tingkat kebutuhan telur ayam ras meningkat menjadi 9.509 ton per tahun, sedangkan kemampuan produksi lokal menjadi 145 ton per tahun. Tahun 2017, angka kebutuhan telur ayam ras menjadi 9.680 ton per tahun, dan tingkat produksi lokal sebesar 224 ton per tahun.

Jika dilihat dari data diatas, perbandingan antara tingkat kebutuhan dan kemampuan produksi lokal pada tahun 2015 sebesar 0,77\%; tahun 2016 sebesar 1,53\%; dan tahun 2017 sebesar 2,31\%. Hal ini berarti pada tahun 2017, market share yang ada masih sangat besar yaitu 96,79\%. Dapat diambil kesimpulan bahwa peluang usaha peternakan ayam ras petelur di Maluku untuk berkembang sangat besar.

\section{Faktor Kompetitif}

Dalam menganalisa industri dan pengembangan strategi bisnis, maka penulis menggunakan PorterFive Forces, yang terdiri dari:

\section{Kekuatan Menawar dari Pembeli}

Karena terdapat banyak pemasok telur ayam ras yang ada, maka pembeli memiliki kekuatan. Jika penjual ingin menarik perhatian pembeli, maka penjual harus menunjukkan kepada pembeli bahwa produknya memiliki keunggulan. Meskipun harga jual telur sudah ditentukan oleh pemerintah, tapi kami dapat menjamin bahwa telur kami memiliki harga yang bersaing dengan kualitas yang baik. Jadi kekuatan menawar dari pembeli adalah tinggi. 
2. Kekuatan Menawar dari Penjual

Penjual telur ayam ras tidak terlalu memiliki kekuatan, karena terdapat banyak pemasok. Sedangkan untuk harga telur yang dijual harus mengikuti standar harga yang ditetapkan oleh pemerintah. Satu-satunya cara agar penjual memiliki kekuatan tawar menawar adalah dengan meningkatkan produktivitas, sehingga biaya produksi rendah dan telur dapat dijual dengan harga yang kompetitif. Jadi kekuatan menawar dari penjual adalah rendah.

3. Hambatan Substitusi Produk

Telur ayam kampung merupakan substitusi produk dari telur ayam ras. Namun, masyarakat lebih menyukai telur ayam ras dikarenakan harga yang murah dan ukurannya lebih besar dari telur ayam kampung. Jadi hambatan substitusi produk adalah rendah.

4. Hambatan Pendatang Baru kedalam Industri

Dalam bisnis peternakan ayam ras petelur, pasti ada pendatang baru. Apalagi ketika melihat kesuksesan para pemain lama. Modal juga menjadi salah satu hambatan masuknya pendatang baru ke industry ini. Lagipula jumlah produksi telur ayam ras oleh peternak lokal masih sangat rendah jika dibandingkan dengan tingkat kebutuhannya. Jadi hambatan pendatang baru ke dalam industry adalah rendah.

5. Kompetisi Antar Sesama Pelaku Usaha

Peternakan ayam petelur yang sudah lebih dahulu ada, masih terhitung muda karena berumur kurang dari 5 tahun dan merupakan peternakan skala kecil menengah. Sehingga manajemen peternakan belum dilakukan dengan baik, yang menyebabkan tingkat capaian produksi masih rendah. Perusahaan kami menerapkan manajemen peternakan yang baik dan tepat guna menekan biaya yang harus dikeluarkan dan menjamin tingginya tingkat produksi. Jadi kompetisi antar sesama pelaku usaha adalah rendah.

\section{Rencana Kerja}

Rencana kerja yang akan dilakukan ketika memulai bisnis ini, terdiri dari beberapa bagian yaitu:

1. Lokasi

Lokasi yang dipilih untuk membangun peternakan ini terletak di Pulau Seram, Provinsi Maluku. Lokasi yang sudah disiapkan sebesar 1 hektar, dimana daerah sekitar masih terdapat banyak lahan kosong, sehingga memungkinkan perluasan daerah peternakan sewaktu-waktu. Lokasi juga memiliki akses jalan yang telah diaspal sehingga memudahkan penyaluran hasil produksi.

\section{Perizinan}

Usaha ini awalnya akan dimulai dengan memelihara 2000 ekor ayam, sehingga izin usaha yang diperlukan adalah izin usaha peternakan rakyat. Izin usaha dipastikan akan mudah diperoleh mengingat adanya komitmen dari Dinas Pertanian Provinsi Maluku yang sedang mendorong munculnya usaha di bidang peternakan ayam ras petelur guna mengurangi tingkat ketergantungan dari daerah lain.

\section{Bangunan Kandang}

Pada bangunan kandang akan dipisahkan menjadi 2 bagian yaitu bangunan kandang luar dan kandang. Bangunan kandang luar yang digunakan berjenis terbuka, 
dikarenakan biaya pembangunan yang murah juga suhu bangunan relative lebih stabil. Tiap bangunan kandang luar yang dibuat memiliki kapasitas penampungan maksimal 1000 ekor ayam.

Sedangkan untuk kandang yang digunakan akan menggunakan kandang baterai. Pada usaha ini, terdapat 3 kandang yaitu kandang DOC (Day Old Chicken), pullet, dan layer. Perbedaan dari ketiga tipe kandang ini terdapat pada fasilitas pendukung, jumlah populasi dan penyusunan kandang. Kandang DOC, dilengkapi dengan pemanas berupa lampu ultraviolet, populasi ayam sekitar 40-55 ekor. Kandang pullet berisi 12-25 ekor ayam, sedangkan kandang layer hanya berisi 1 ekor ayam dan dilengkapi dengan tempat penampung telur. Kandang akan disusun membentuk huruf $\mathrm{V}$ dan bertingkat, dimana 2 tingkat untuk kandang layer dan 3 tingkat untuk kandang DOC dan pullet.

4. Kepemilikan

Dalam mendukung keberhasilan usaha ini, diperlukan penanaman modal yang berasal dari investor disamping menggunakan modal pribadi. Total investasi awal yang diperlukan untuk menjalankan bisnis ini sebesar $\mathrm{Rp} 1.000 .000 .000$,- (satu milyar rupiah), dimana kepemilikan oleh pemilik sebesar $70 \%$ dan investor sebesar $30 \%$. Jumlah investor sendiri dibatasi maksimal 2 orang.

\section{Manajemen Peternakan Ayam Petelur}

Dalam menjalankan bisnis peternakan ayam ras petelur ini, diperlukan manajemen yang baik dan ketat sehingga dapat mencapai tingkat produktivitas yang tinggi dan dapat menekan biaya yang harus dikeluarkan. Manajemen peternakan ayam ras petelur terdiri dari beberapa bagian yaitu:

\section{Pemilihan DOC}

Ayam ras petelur yang akan diternakan adalah ayam medium jenis Hisex Brown, dimana memiliki ketahanan tubuh lebih kuat dari ayam petelur ringan. Dalam setahun dapat menghasilkan 270-290 butir telur berwarna coklat dengan bobot rata-rata tiap butir sebesar 64 gram. Pemasok DOC merupakan perusahaan ternak yang terkenal dan memiliki kredibilitas yang baik, sehingga menjamin DOC yang dibeli memiliki kualitas yang baik. Mengingat kualitas DOC merupakan penentu keberhasilan peternakan ayam ras petelur.

2. Biosekuriti

Biosekuriti merupakan serangkaian kegiatan yang dilakukan untuk mencegah penyakit masuk ke dalam peternakan dan menyebar ke luar peternakan. Biosekuriti harus dilakukan sejak awal memulai usaha dengan pengerjaan yang sempurna. Biosekuriti terdiri dari:

a. Isolasi. Dilakukan untuk mencegah bibit penyakit masuk ke dalam peternakan dan menyebar ke luar peternakan. Salah satu caranya adalah penerapan area bersih dan area kotor serta pencegahan masuknya hewan lain ke lingkungan kandang.

b. Kontrol Lalu Lintas. Merupakan pengaturan lalu lintas orang, peralatan, barang dan kendaraan.

c. Sanitasi. Dilakukan untuk mencegah berkembang biaknya penyakit dan memotong siklus hidup mikroorganisme yang merugikan kesehatan ayam. Salah satu cara sanitasi adalah pembersihan kandang dan peralatan menggunakan disenfektan dalam jangka waktu tertentu.

3. Vaksinasi

Dilakukan untuk merangsang pembentukan antibody alami pada ayam untuk melawan serangan penyakit tertentu. Pemberian vaksin dilakukan sejak ayam berumur 0 
sampai 2 bulan, yang dilakukan secara ketat, menyeluruh dan sesuai aturan yang ada. Terdapat 3 cara pemberian vaksin yaitu:

a. Vaksinasi melalui air minum, dicampur dengan air minum.

b. Vaksinasi tetes, diberikan melalui mata.

c. Vaksinasi suntik, menggunakan bantuan injector.

4. Manajemen Pakan

Pakan merupakan komponen biaya operasional paling besar dalam peternakan ayam petelur, yaitu sekitar $65-80 \%$ dari total biaya produksi. Oleh karena itu, manajemen pemberian pakan harus dilakukan secara tepat agar pertumbuhan ayam dapat maksimal dan mencapai tingkat produksi. Pakan diberikan sesuai kebutuhan ayam. Pakan yang berasal dari pabrik sudah memiliki kandungan nutrisi yang ideal bagi ayam dan sesuai dengan umur ayam. Namun, untuk menghemat biaya, pakan dapat dibuat sendiri. Pakan yang dibuat sendiri harus terdapat kandungan nutrisi seperti karbohidrat, lemak, protein, mineral, dan vitamin. Pemberian pakan harus diberikan secara merata. Yang tidak kalah penting dalam manajemen pakan adalah penyimpanan pakan. Pakan disimpan tidak boleh lebih dari 14 hari, dan harus disimpan di gudang pakan dengan pakan dengan memperhatikan suhu, kelembapan, kebersihan, layout, serta bebas dari kontaminasi

5. Manajemen Minum

Air merupakan elemen penting dalam manajemen peternakan yang tidak dapat digantikan oleh apapun. Air merupakan komponen terbesar penyusun tubuh ayam sehinggan air menjadi nutrient yang harus selalu tersedia. Air minum ayam harus terbebas dari kontaminasi limbah, sehingga sumber air minum harus selalu dijaga kebersihannya. Pemberian air yang memiliki kualitas rendah akan menyebabkan gangguan pada produktivitas ayam, baik pertumbuhan dan produksi telur, dan dapat menyebabkan kematian.

6. Manajemen Pemeliharaan

Manajemen pemeliharaan dilakukan secara berbeda tergantung tingkatan umur ayam, dikarenakan tiap tingkatan umur ayam memiliki kebutuhan dan cara penanganan yang berbeda. Oleh karena itu, terdapat 3 tipe manajemen pemeliharaan, yaitu:

a. Manajemen pemeliharaan DOC

DOC merupakan masa pemeliharaan yang paling kritis selama masa pertumbuhan ayam, sehingga harus hati-hati dalam merawatnya. Kegagalan pada fase ini akan menyebabkan kegagalan di masa pemeliharaan selanjutnya, dimana akan menyebabkan menurunnya produktivitas ayam. Kegagalan pada masa ini biasanya disebabkan oleh pemberian pakan, penggunaaan pemanas, dan program vaksinasi yang kurang tepat.

b. Manajemen pemeliharaan pullet

Pemeliharaan pada masa ini dilakukan sejak ayam berumur 4 minggu hingga 18 minggu. Pemeliharaan pada masa ini memiliki tujuan untuk mendapatkan ayam yang sehat, kuat, memiliki pertumbuhan yang seragam, dan untuk memperoleh ayam dewasa yang memiliki produktivitas yang optimal. Karena pada masa pertumbuhan inilah merupakan saat yang terbaik untuk menghasilkan ayam yang produktif. Manajemen pada masa ini meliputi pemberian pakan penumbuh yang baik, air minum yang selalu tersedia dan bersih, sanitasi yang baik, dan pastikan binatang pemangsa tidak dapat memasuki kandang di malam hari.

c. Manajemen pemeliharaan layer

Pemeliharaan pada masa ini dimulai sejak ayam mulai menghasilkan telur pada umur 18 minggu hingga 20 bulan. Pada masa ini, ayam harus mendapatkan pakan 
sebaik mungkin untuk menjamin produktivitasnya, dimana kebutuhan akan protein lebih tinggi dari masa pemeliharaan sebelumnya. Pada masa ini juga diperlukan adanya recording yang tertib. Adanya recording yang akurat akan mempermudah proses evaluasi, pengontrolan, dan memprediksi tingkat keberhasilan usaha.

7. Manajemen Pengendalian Penyakit

Dilakukan untuk mencegah dan mengendalikan penularan serangan penyakit pada ayam. Dengan melakukan manajemen pengendalian yang baik dapat mencegah terjadinya penurunan produktivitas dan bahkan kematian pada ayam. Beberapa penyakit yang umumnya menyerang ayam petelur, yaitu:

a. Newcastle Dieseases (ND). Disebabkan oleh Paramyxovirus, menyebabkan gangguan pada saluran pernafasan dan saraf yang disusul dengan penurunan produktivitas dan kualitas telur serta kematian. Gejala pada ayam yang terkena penyakit ini adalah ketidakseimbangan pergerakan, leher seperti terpelintir, dan gangguan pernafasan. Sampai saat ini belum ada obat yang dapat menyembuhkan ND. Hanya vaksinasi ND yang dilakukan sebagai langkah pencegahan.

b. Infectious Bronchitis (IB). Disebabkan oleh Coronavirus, menyerang saluran pernapasan dan reproduksi, dan dapat menyebabkan kematian pada ayam muda. Gejalanya adalah ayam menderita ngorok, batuk, dan mata berair. Ciri khas dari ayam yang terkena penyakit ini adalah adanya bloodspot pada putih telur. Sampai saat ini belum ada obat untuk penyakit ini, hanya ada langkah pencegahan yaitu berupa pemberian vaksin IB secara teratur.

c. Egg Drop's Syndrome (EDS). Disebabkan oleh virus EDS-76. Gejala dapat dilihat pada penurunan produksi telur, telur lembek seperti telur penyu, dan tidak memiliki bloodspot. Penyakit ini belum ada obatnya, hanya digunakan vaksinasi sebagai tindakan pencegahan.

d. Chronic Respiratory Disease (CRD). Disebabkan oleh bakteri Mycoplasma gallisepticum. Gejala penyakit ini adalah mata berair, ngorok, liliran nostril, daerah sinus membengkak. Ciri khas telur yang dihasilkan memiliki sandy egg, yaitu bintik-bintik material cangkang telur pada permukaan kulit telur lebih dari $1 \%$. Pengobatan untuk penyakit ini adalah dengan memberikan antibiotic sesuai dengan dosis yang dianjurkan oleh pabrik. Sedangkan untuk langkah pencegahan adalah dengan memastikan ventilasi udara baik dan tidak lembap, menjaga lingkungan kandang supaya segar, sehat dan tidak pengap.

e. Cacingan. Cacing yang menyerang ayam ada dua golongan, yaitu Cacing Gilig dan Cacing Pipih Pita. Gejala ayam yang terkena cacingan adalah badan ayam kerdil, penurunan pertumbuhan dan berat badan, bulu kusam, diare, dan penurunan produksi telur. Pengobatan pada ayam yang terserang cacingan adalah dengan memberikan obat cacing, sedangkan untuk langkah pencegahan adalah dengan menjaga kebersihan kandang, mencegah adanya kontak langsung antara ayam dengan kotoran, membersihkan kotoran minimal 3 minggu sekali.

f. Mikotoksikosis. Disebabkan oleh Okratoksikosis. Gejala ayam yang terkena penyakit ini adalah cangkang telur yang dihasilkan mulai pucat, ukuran telur tidak seragam, berat telur menurun drastis, dan cangkang telur yang sangat tipis. Langkah pencegahan serangan penyakit ini adalah dengan mengontrol kualitas bahan pakan dan sistem penyimpanan.

\section{Pemasaran}

Tujuan pemasaran dari produk yang dihasilkan adalah pedagang eceran yang memiliki kios di pasar tradisional, toko kelontong yang berada di daerah pemukiman 
penduduk, dan pengepul antar wilayah. Dalam proses pemasaran, akan diimplementasikan strategi marketing mix 4P, yaitu Product, Price, Place, dan Promotion.

\section{Pengembangan Usaha}

Dalam rencana pengembangan usaha kedepannya, kami akan melakukan beberapa hal antara lain mengganti peralatan yang sudah tidak produktif dengan peralatan modern, meningkatkan kualitas sumber daya manusia melalui pelatihan dan seminar, ikut serta dalam komunitas pengusaha ayam ras petelur guna membangun jaringan dan pertukaran informasi, dan secara terus menerus melakukan perbaikan dalam manajemen kandang, lingkungan dan pemeliharaan.

\section{Peralatan}

Peralatan diperlukan untuk menunjang berjalannya usaha peternakan ini dengan baik. Peralatan yang akan digunakan sudah melewati tahap peninjauan dari beberapa sumber yang ada. Sehingga memiliki manfaat yang lebih bagi produktivitas peternakan. Peralatan yang diperlukan adalah talang pakan dari alumunium, nipple, drip cup, lampu ultraviolet, egg tray, filter air, water regulator untuk memastikan tekanan air pada setiap nipple terbagi secara rata dan kecukupan air minum selalu terpenuhi, tandon air, terpal, pallet plastik, timbangan duduk, dan timbangan digital.

\section{Rencana Manajemen}

Rencana manajemen dari perusahaan ini masih tergolong sederhana mengingat merupakan perusahaan baru. Tidak menutup kemungkinan terdapat beberapa individu yang akan menduduki posisi yang berbeda. Komposisi tim dalam perusahaan ini beserta tugas dan tanggung jawab adalah sebagai berikut:

a. Direktur. Bertanggung jawab kepada pemegang saham, dan memastikan perusahaan berjalan dengan baik dan selalu mendapatkan keuntungan. Membawahi manajer operasional dan manajer keuangan dan pemasaran.

b. Manajer Operasional. Bertanggung jawab kepada direktur, bertugas memastikan dan mengontrol seluruh proses operasional perusahaan berjalan dengan baik. Membawahi bagian produksi, kebersihan dan kesehatan, dan juga sopir.

c. Manajer Keuangan dan Pemasaran. Bertanggung jawab kepada direktur, bertugas mengurus keuangan dan administrasi perusahaan, serta pemasaran hasil produksi. Membawahi bagian administrasi dan bagian pemasaran.

d. Bagian Produksi. Bertanggung jawab kepada manajer operasional, bertugas menangani kebutuhan ayam berupa pemberian pakan dan minum, menjamin ketersediaan pakan di gudang pakan, dan pengumpulan dan pengemasan telur.

e. Bagian Kebersihan dan Kesehatan. Bertanggung jawab kepada manajer operasional, bertugas memastikan semua peralatan yang digunakan sudah di sanitasi, jadwal vaksinasi ayam, pembersihan kandang dan penanganan kotoran ayam.

f. Sopir. Bertanggung jawab kepada manajer operasional, bertugas dalam pengiriman hasil produksi.

g. Bagian Administrasi. Bertanggung jawab kepada manajer keuangan dan pemasaran, bertugas menangani administrasi perusahaan, pembuatan laporan laba rugi dan arus kas perusahaan, serta menangani recording ayam petelur.

h. Bagian Pemasaran. Bertanggung jawab kepada manajer keuangan dan pemasaran, bertugas memasarkan hasil produksi perusahaan, bertanggung jawab atas kegiatan penjualan perusahaan, dan menerima saran dari mitra kerja.

\section{Komunikasi}


Bagi investor, komunikasi akan dilakukan melalui e-mail yang berisi laporan keuangan yang akan dikirimkan setiap bulan pada akhir bulan dan rencana kerja perusahaan untuk periode 3 bulan ke depan yang akan dikirimkan pada bulan pertama. Bagi pelanggan, saluran komunikasi formal dilakukan melalui nota pembelian dan pemesanan. Bagi pegawai, saluran komunikasi yang digunakan adalah komunikasi vertikal, baik itu top-down maupun bottomup, dimana pegawai bebas menyampaikan buah pemikirannya pada rapat yang dilaksanakan tiap akhir minggu. Bagi mitra kerja, saluran komunikasi berupa surat perjanjian.

\section{Rencana Keuangan}

Rencana keuangan yang dihitung adalah Laporan Laba Rugi dan Arus Kas, sementara untuk kelayakan investasi adalah NPV dan Payback Period. Laporan Laba Rugi dapat dilihat pada Table 1, dimana terdapat beberapa komponen-komponen biaya yang dihitung yaitu:

a. Pendapatan. Pendapat diperoleh dari penjualan produk berupa telur ayam ras, daging ayam afkir dan kotoran ayam. Asumsi yang digunakan tingkat mortalitas 6\%, telur yang dihasilkan tiap ekor ayam per bulan adalah 23 butir, dan kotoran yang dihasilkan 30 karung per bulan per seribu ekor. Jumlah ayam untuk tahun pertama dan kedua adalah 2000, mulai tahun 3 sampai 5 terdapat penambahan jumlah ayam sebanyak 1000 ekor tiap tahun.

b. Pengeluaran. Komponen pengeluaran terdiri dari pembelian ayam siap telur di tahun pertama, bibit DOC, air dan listrik, gaji, pakan ternak, vaksin dan vitamin, alat tulis kantor, transportasi, promosi, dan pelatihan.

c. Depresiasi. Komponen depresiasi adalah bangunan DOC, bangunan pullet, bangunan layer, kandang DOC dan pullet, kandang layer, mobil, peralatan kandang, dan peralatan kantor.

d. Pajak. Pajak yang ditetapkan pemerintah yaitu $1 \%$ dari pendapatan.

Table

Laporan Laba Rugi Tahun 1 - Tahun 5

(dalam juta Rupiah)

\begin{tabular}{|l|l|l|l|l|l|}
\hline Komponen Biaya & Tahun 1 & Tahun 2 & Tahun 3 & Tahun 4 & Tahun 5 \\
\hline Pendapatan & 651,60 & 847,72 & $1.108,36$ & $1.499,32$ & $1.923,18$ \\
\hline Pengeluaran & 532,90 & 551,38 & 810,12 & $1.085,02$ & $1.329,76$ \\
\hline Depresiasi & 71,59 & 71,59 & 96,55 & 113,26 & 129,97 \\
\hline Total Pengeluaran & 604,49 & 622,97 & 906,67 & $1.198,28$ & $1.459,73$ \\
\hline EBT & 47,11 & 224,75 & 201,69 & 301,040 & 463,45 \\
\hline Pajak & 6,52 & 8,48 & 11,08 & 14,99 & 19,23 \\
\hline Laba Bersih & 40,59 & 216,273 & 190,61 & 286,05 & 444,22 \\
\hline
\end{tabular}

Laporan Arus Kas dapat dilihat pada Table 2, dimana terdapat komponen-komponen biaya yang dihitung yaitu:

a. Operasional. Terdiri dari laba bersih, depresiasi, dan pajak.

b. Investasi. Terdiri dari biaya bangunan DOC, bangunan pullet, bangunan layer, kandang DOC dan pullet, kandang layer, mobil, peralatan kandang, dan peralatan kantor

c. Pendanaan. Terdiri dari modal dan dividen. Dividen sebesar 50\% dari laba bersih, diberikan pada tahun 4 dan tahun 5 . 
Table

Laporan Arus Kas Tahun 1 - Tahun 5

(dalam juta Rupiah)

\begin{tabular}{|l|l|l|l|l|l|}
\hline Komponen Biaya & Tahun 1 & Tahun 2 & Tahun 3 & Tahun 4 & Tahun 5 \\
\hline Operasional & 118,70 & 296,34 & 298,24 & 414,30 & 593,42 \\
\hline Investasi & $(769,00)$ & $(0)$ & $(230,00)$ & $(155,00)$ & $(155,00)$ \\
\hline Pendanaan & 1.000 & 0 & 0 & $(143,02)$ & $(222,11)$ \\
\hline Perubahan Kas & 349,70 & 296,34 & 68,24 & 116,28 & 216,31 \\
\hline Kas Tahun Lalu & 0 & 349,70 & 646,04 & 714,28 & 830,57 \\
\hline Kas Tahun Ini & 349,70 & 646,04 & 714,28 & 830,57 & $1.046,87$ \\
\hline
\end{tabular}

Analisis NPV dapa dilihat pada Table 3, dimana discount factor yang digunakan adalah sebesar $9.75 \%$. Dapat dilihat bahwa NPV bernilai positif yang menunjukan bahwa usaha layak untuk dilaksanakan

Table

Net Present Value

\begin{tabular}{|l|l|l|l|}
\hline Tahun & Kas Bersih & DF 9.75\% & PV Kas Bersih \\
\hline 1 & $112,184,000$ & 0.91 & $102,087,440$ \\
\hline 2 & $287,862,800$ & 0.83 & $238,926,124$ \\
\hline 3 & $287,156,400$ & 0.76 & $218,238,864$ \\
\hline 4 & $399,306,800$ & 0.69 & $275,521,692$ \\
\hline 5 & $574,188,200$ & 0.63 & $361,738,566$ \\
\hline \multicolumn{2}{|l}{ PV Kas Bersih } & $1,196,512,686$ \\
\hline \multicolumn{2}{|l}{ PV Investasi } & $1,000,000,000$ \\
\hline NPV & $196,512,686$ \\
\hline
\end{tabular}

Analisis Payback Period dapat dilihat pada Table 4. Dari perhitungan yang diperoleh hasil yaitu waktu pengembalian investasi adalah 3,94 tahun.

Table

Payback Period

\begin{tabular}{|l|l|l|}
\hline Tahun & Kas Bersih & Kumulatif \\
\hline 1 & $112,184,000$ & $112,184,000$ \\
\hline 2 & $287,862,800$ & $400,046,800$ \\
\hline 3 & $287,156,400$ & $\mathbf{6 8 7 , 2 0 3 , 2 0 0}$ \\
\hline 4 & $399,306,800$ & $1,086,510,000$ \\
\hline 5 & $574,188,200$ & $1,660,698,200$ \\
\hline
\end{tabular}

$$
\begin{aligned}
\text { Payback period } & =3+\frac{(1,000,000,000-687,203,200)}{399,306,800} \times 12 \text { bulan } \\
& =3+9.4 \text { bulan } \\
& =3.94 \text { tahun }
\end{aligned}
$$




\section{KESIMPULAN DAN SARAN}

Berdasarkan penelitian terhadap usaha peternakan ayam ras petelur PT. Sinar Farm di Maluku, maka dari hasil analisis dan pembahasan dapat diambil kesimpulan:

1. Pada tahun 2017, terdapat market share telur ayam ras sebesar $97.69 \%$, yang berarti masih sangat luas peluang usaha peternakan ayam ras petelur di Maluku.

2. Nilai investasi usaha ini sebesar Rp 1.000.000.000,- dimana seluruh modal berasal dari pemegang saham dengan komposisi pemilik $70 \%$ dan investor $30 \%$.

3. Hasil perhitungan NPV usaha ini menunjukan hasil positif yaitu sebesar Rp 196.512.686,- dengan discount factor sebesar 9,75\%, sehingga layak untuk berinvestasi pada usaha ini.

4. Dari analisis Payback Period, jangka waktu pengembalian investasi adalah 3,94 tahun.

Dari hasil penelitian ini, terdapat beberapa saran untuk meningkatkan keakuratan rencana bisnis ini, yaitu:

1. Penyusunan analisis keuangan memperhitungkan nilai waktu terhadap uang agar dapat memberikan estimasi yang lebih akurat.

2. Rencana bisnis dalam penelitian ini hanya ditinjau berdasarkan sumber data sekunder, untuk mendapatkan hasil yang lebih baik dapat dilakukan penelitian lebih lanjut dengan meninjau langsung ke lapangan.

\section{DAFTAR PUSTAKA}

Dollinger, M. J. (2002). Entrepreneurship: Strategies and Resources. Upper Saddle River: Pearson.

Erni Sulindawati, N. G., Yuniarta, G. A., \& Purnamawati, I. A. (2017). Manajemen Keuangan Sebagai Dasar Pengambilan Keputusan Bisnis. Depok: Rajawali Pers.

Hien, K. S., \& Mariani, F. I. (2017). Financial Management Canvas. Jakarta: Elex Media Komputindo.

Munster, R. (2015, April 15). Distan Maluku Dorong Warga Kembangkan Peternakan Ayam. (J. Nikita, Editor) Retrieved May 24, 2018, from ANTARAMALUKU: https://ambon.antaranews.com/berita/23758/distan-maluku-dorong-wargakembangkan-peternakan-ayam

Pajak di Bisnis Peternakan. (2018, February 1). Retrieved May 24, 2018, from Trobos Livestock: http://www.trobos.com/detail-berita/2018/02/01/7/9820/pajak-di-bisnispeternakan

Populasi Ayam Ras Petelur menurut Provinsi, 2009-2016. (2015, December 18). Retrieved May 24, 2018, from Badan Pusat Statistik: https://www.bps.go.id/dynamictable/2015/12/18/1031/populasi-ayam-ras-petelurmenurut-provinsi-2009-2016.html

Produksi Telur Ayam Petelur menurut Provinsi, 2009-2015. (2015, December 22). Retrieved May 24, 2018, from Badan Pusat Statistik: https://www.bps.go.id/dynamictable/2015/12/22/1079/produksi-telur-ayam-petelurmenurut-provinsi-2009-2015.html

Raharjo, Y. (2016). Beternak Ayam Petelur. Bandung: Penerbit Nuansa.

Ustomo, E. (2017). 99\% Gagal Beternak Ayam Petelur. Jakarta: Penebar Swadaya. 
